\title{
Decreased Protein C Levels in Endomyocardial Fibrosis: The Possible Significance
}

Prabha Nini Gupta*, Kumaralingam G Balakrishnan and Kartha CC

ICMR Centre for Research in Cardiomyopathies, Sri Chitra Tirunal Institute for Medical Sciences and Technology, Trivandrum, India

\begin{abstract}
The occurrence of frequent intracardiac thrombi in Endomyocardial fibrosis, and the embolization of these thrombi contributing to the morbidity is an established fact. Since previous studies on endomyocardial fibrosis revealed normal prothrombin time, clotting times, bleeding time, it was considered worthwhile to investigate whether an inherited deficiency of protein $\mathrm{C}$ contributed to thrombosis in these patients.

Measurements of protein C functional levels revealed that $17 / 18(94.4 \%)$ of patients tested and $4 / 18$ of the healthy controls were functionally deficient $(p<.001)$ while the antigenic levels of 7 patients and 3 controls were deficient. It was observed that $5.55 \%$ and $44.4 \%$ of patients had normal profiles and Type 1 deficiency respectively, while $44.4 \%$ had Type II deficiency. This association between protein $\mathrm{C}$ deficiency and endomyocardial fibrosis may contribute to the formation of intracardiac thrombi in these patients.
\end{abstract}

Keywords: Endomyocardial fibrosis; Protein C estimation; Intracardiac thrombosis; Cardiomyopathy; Antigenic and functional assays

\section{Introduction}

Endomyocardial fibrosis is a disease of unknown aetiology associated with endocardial thickening and apical and trabecular obliteration of the right ventricle or left ventricle. This is also associated with increased myocardial fibrosis. Primarily in endomyocardial fibrosis obliteration of the apexes and the trabecular portion of the ventricles is associated with diastolic dysfunction and latter compensatory dilatation of the right and left atria. So endomyocardial fibrosis has a unique combination of reduced flow in the ventricles with cavity dilatation. As per Virchow's triad this is associated with stasis and thrombosis. But the thrombosis in endomyocardial fibrosis appears to be out of proportion to the incidence of just dilatation of the cavities. So we thought that we should look into whether in addition to the thrombosis seen due to chamber dilatation whether a primary clotting or coagulation abnormality was co existing to cause intracavitary thrombosis in EMF.

Many authors like Davies, D’ Arbela and Somers have described extensive intracavitary thrombi [1-3]. In two studies by us also we have found intracavitary thrombi $[4,5]$. So we wondered whether the coagulation abnormality came first or the chamber dilatation came first. We postulated that the risk of intracardiac thrombi would be more than the general population, or RHD patients if coagulation abnormalities were a part of the disease in endomyocardial fibrosis. We planned to study 3 aspects, one of which is presented in this study. They were-Protein $\mathrm{C}$ levels in endomyocardial fibrosis, Protein $\mathrm{S}$ in endomyocardial fibrosis and platelet aggregation studies.

Protein $\mathrm{C}$ is the zymogen of a serine protease, involved in blood coagulation [6]. Previous studies have linked Protein $\mathrm{C}$ deficiency to venous thrombosis. Other studies have linked it to arterial thrombosis. So it would be possible that protein $\mathrm{C}$ deficiency could be associated with intracavitary thrombosis also.

Activated protein $\mathrm{C}$ destroys the activity of activated factor $\mathrm{V}$ and VIIl [7] and stimulates fibrinolysis by inducing a rise in plasma plasminogen activity. Protein $\mathrm{C}$ is a potent natural anticoagulant, and hereditary deficiencies of protein $\mathrm{C}$ have been described [8]. At least two types of hereditary protein $\mathrm{C}$ deficiencies can be recognized at present. In type I deficiency protein $\mathrm{C}$ activity and or protein $\mathrm{C}$ antigen are below the normal range while the ratio between protein $\mathrm{C}$ activity and antigen is within normal range [9].

In type 2 deficiency protein $\mathrm{C}$ antigen is within normal ranges while protein $\mathrm{C}$ activity is below the normal range.

Type I patients have been shown to have and increased predeliction for venous thrombosis and pulmonary infarction.

Endomyocardial fibrosis is a cardiomyopathy of unknown aetiology characterized by the frequent occurrence of intracardiac thrombi [10], and deep vein thrombosis [11]. These have been shown to adversely affect the prognosis of patients with endomyocardial fibrosis. In echocardiographic, cardiac catheterization [11], autopsy [12] and surgical series [13] intracardiac thrombi have been observed. Previous studies on the haematological profile in endomyocardial fibrosis from Kerala were normal, a search for fibrin degradation products yielded a positive result only in one (3.85\%) of the 26 patients studied [14].

\section{Material and Methods}

\section{Sample collection}

Blood was collected in an 11 Disodium citrate in the proportion 9:1 and centrifuged at 1600-2000 $\times 9$ for 10 minutes. The decanted plasma was frozen at -20 degrees $C$ and thawed immediately before use.

\section{Patients}

Only patients in whom the diagnosis of endomyocardial fibrosis

*Corresponding author: Prabha Nini Gupta, ICMR Centre for Research in Cardiomyopathies, Sri Chitra Tirunal Institute for Medical Sciences and Technology, T/C 5/2091, Near the Sri Krishna Temple, Cheruvekkal, Srikaryam, Trivandrum-695017, Kerala, India, Tel: 00917736828055; E-mail: ninigupta@gmail.com

Received September 24, 2013; Accepted October 31, 2013; Published November 03, 2013

Citation: Gupta PN, Balakrishnan KG, Kartha CC (2013) Decreased Protein C Levels in Endomyocardial Fibrosis: The Possible Significance. J Blood Disorders Transf 4: 170. doi: 10.4172/2155-9864.1000170

Copyright: (c) 2013 Gupta PN, et al. This is an open-access article distributed under the terms of the Creative Commons Attribution License, which permits unrestricted use, distribution, and reproduction in any medium, provided the original author and source are credited. 
was confirmed at cardiac catheterization were included in the study. Of these 18 patients, 15 patients were male and 3 were female. Of necessity only 18 patients and controls could be done from one kit, as one kit from American diagonostica contained only material sufficient for this. The kits took almost 6 months to arrive after ordering so any second kit would have to be ordered and used after a gap. At the time of the study this gap was considered inappropriate. The serum samples were collected and used on the same day of collection but the antigenic studies were done all together on electrophoretic plates. It was considered that keeping the samples too long would alter the results. So the best analysis that could be done at the time was performed.

Further the number of patients was limited by-the patient should have normal liver function tests, should be off warfarin and should not be on aspirin. All these conditions were met when the patient came for catheterization admission, the warfarin would be stopped and only patients with normal liver function were taken in the study. Echo proven cases were not accepted at this time as this was not the gold standard for EMF previously.

These patients were all patients admitted to the Sri Chitra Tirunal Institute of Medical Sciences and Technology, under the department of Cardiology, Trivandrum, Kerala, India. They are part of a large natural history series of patients from the same institute [4]. The samples were collected fasting by venepuncture. The first author worked in this institute as a research fellow. This study was funded by funds from the ICMR.

The ages ranged from 10-50 years. The patient details are given in Table 1. Consecutive patients who were admitted for catheterization and who were willing to give blood samples were included in the study. Patients with cardiac failure, on warfarin or aspirin or with fever or inflammation were excluded from the study. None of the patients had cardiac failure at the time of taking the blood sample, none was taking oral anticoagulants, none had hepatomegaly, nor were any of the female patients on oral contraceptives. Controls were matched for age and sex. They were voluntary blood donors to the institute in whom PRP had been prepared for other purposes. Their plasma was taken. No patient had any inflammation or infection or features of DIC as they were thoroughly checked for undergoing cardiac catheterization. Rheumatic heart disease patients were not considered as they may have had intracardiac thrombi so they were not considered as controls. All patients were those

\begin{tabular}{|l|c|}
\hline \multicolumn{1}{|c|}{\begin{tabular}{c} 
Agex \\
\multicolumn{1}{|c|}{ Mean \pm SD $\mathbf{2 5 . 2 7} \pm \mathbf{1 0}$}
\end{tabular}} & $\begin{array}{c}\text { Female-3 } \\
\text { (range 10-50 years) }\end{array}$ \\
\hline Type of Endomyocardial Fibrosis: & 18 \\
\hline Biventricular & 10 \\
\hline Predominant involvement of the left ventricle & 8 \\
\hline Predominant involvement of the right ventricle & 0 \\
\hline Cardiac Failure & 0 \\
\hline Hepatic enlargement & $10.16 .+4.2 \mathrm{~mm} \mathrm{Hg}$ \\
\hline Catheterization findings: & $12.76+11.84 . \mathrm{mm} \mathrm{Hg}$ \\
\hline Right atrial mean pressure & $22.29+11.84 \mathrm{~mm} \mathrm{Hg}$ \\
\hline Mean Right ventricular end diastolic pressure & $37.76+20.69 \mathrm{mmHg}$ \\
\hline Left ventricular end diastolic pressure & \\
\hline Pulmonary artery means pressure & $2(1-\mathrm{LV}, 1-\mathrm{RA})$ \\
\hline Echocardiographic Findings: & $4.31+1.37 \mathrm{~cm}$ \\
\hline Intracardiac thrombi & $2.6+.9016 \mathrm{~cm}$ \\
\hline Left ventricular internal dimension diastolic & $39.79+9.99 \%$ \\
\hline Left ventricular internal dimension systolic & \\
\hline Fractional Shortening &
\end{tabular}

Table 1: Clinical profile of patients with Endomyocardial fibrosis. who presented to Sri Chitra Tirunal Institute of Medical Sciences and Technology, Trivandrum, Kerala (From 1987-1988).

Two patients had intracardiac thrombi, one patient, age 20, (male) had a left ventricular thrombosis and the other also a 20 year old male had a right atrial thrombosis.

\section{Protein C estimation}

Protein C estimation was carried out by two methods; both methods were employed in all patients and controls.

\section{An Immunological assay}

Here the protein $\mathrm{C}$ antigen was measured by Laurell Rocket electrophoresis.

Principle: Protein C would migrate in an electrical field in $1 \%$ agarose gel medium containing protein $\mathrm{C}$ specific IgG, $0.7 \%$ goat antihuman protein C IgG (American Diagnostics-one kit) was incorporated into the gel, and electrophoresed for 3 hours at $16 \mathrm{~mA} /$ plate using a buffer at $\mathrm{pH} 8.6$, containing .081 M Tris and .024 Tricine.

Plasma samples of patients, controls and standards (supplied with the other kit reagents) were run simultaneously. The plates were washed gently in $0.9 \%$ saline, press dried and stained with commassie blue and destained with ethanol and glacial acetic acid and contact prints (without any enlargement were taken and the height of each rocket shaped precipitin was measured. A standard curve was drawn on bicycle logarithmic paper with standards and the protein $\mathrm{C}$ levels in the sample plasma were determined by interpolating form the standard curve. All samples were tested in this way.

\section{Functional assay for protein C}

Principle: A rapid protein $\mathrm{C}$ activator derived from viper venom (American Diagnostic Inc.) converts human protein $\mathrm{C}$ to the active protease $\mathrm{C}$ within 5 minutes. This reagent was co-lyophilized with APTT (activated partial thromboplastin time reagent, supplied with the kit).

Therefore $100 \mathrm{ul}$ of the activator, $100 \mathrm{ul}$ of the protein $\mathrm{C}$ deficient plasma (also supplied with the kit and used to dilute the unknown specimen to a visible end point and to supply factors V and VIII ) with $100 \mathrm{ul}$ of diluted plasma (of either the patient or the control) were mixed together. All of the above were added to $250 \mathrm{ul}$ of imidazole buffered saline at a $\mathrm{pH}$ of 7.4 , (supplied with the kit) were incubated together for 5 minutes at 37 degrees $\mathrm{C}, 100 \mathrm{ul}$ of calcium chloride $(.025 \mathrm{~m})$ was added and the time taken for forming a visible clot was measured.

Protein C control plasma (supplied with the kit) was tested by the above method in 100\%, 75\%, 50\% and $25 \%$ dilutions and a standard curve plotted on linear graph paper. The percentage of protein $\mathrm{C}$ from unknown plasma (either patients or controls) was interpolated from the standard curve.

\section{Results}

Of the 18 patients and 18 controls only $1 / 18$ (5.55\%) of patients and $12 / 18$ of controls $(66.6 \%)$ had normal profiles of protein C (Normal protein $\mathrm{C}$ functional activity and normal antigenic levels, $\mathrm{p}<.001$ ) $(\mathrm{X} 2=14.56)$

We are probably the first paper to study protein $\mathrm{C}$ in a Kerala population. The existing level of deficiency of protein $\mathrm{C}$ in this population (South Asian) has not yet been reported. This may be why 6 controls had some form of protein $\mathrm{C}$ deficiency. These were age and 
sex matched controls that had come for routine blood donation to the institute. In our study we had two young patients (around 10 years of age) their age and sex matched controls were around 20 years. (On consulting the statistician the age group for the control could be within the 10 years of the patient). We did not take rheumatic heart disease as these patients can also have intracardiac thrombosis.

The mean values in patients and controls are given in Table 2.

Of the remaining 17 patients $8,(44.44 \%)$ had normal antigenic levels. (Mean $98.60+16.08 \%$ ) (Table 3) while the functional levels of protein $\mathrm{C}$ were deficient $(\mathrm{n}=8,47.25+15.08 \%)$. These profiles resembled the type II protein $\mathrm{C}$ deficiency previously described. One patient had an atypical deficiency. The antigenic protein $\mathrm{C}$ levels were $24.25 \%$ (decreased) but the functional levels were normal (130\%). The remaining 8 patients had decreased antigenic levels $(63.125+21.4 \%)$ and depressed protein $\mathrm{C}$ functional levels. $(59.68+22.86, \mathrm{n}=8)$ suggestive of Type I protein $\mathrm{C}$ deficiency.

\section{Relatives}

The protein $\mathrm{C}$ levels were available in the parents of 2 patients. One of our patient's father and the proband both had type II deficiency while his mother had a normal profile.

The other patient's mother had Type I protein C deficiency. This was the same as her son. He also had Type 1 protein $\mathrm{C}$ deficiency. His father's could not be done has he had died 10 years before the study.

The normal range reported for protein $\mathrm{C}$ functional activity ranges from $75-150 \%$ and the antigenic form ranges from $61-120 \%$.

\section{EMF patients had deficient functional levels of Protein C}

If only the protein Cactivity was taken, patients with endomyocardial fibrosis have a significantly lower functional level of Protein C. This would definitely promote intracavitary thrombosis. But the Type of Protein $\mathrm{C}$ deficiency is usually typed only after testing its antigenic level. As can be seen from Table 2 the antigenic levels of Protein $\mathrm{C}$ in emf patients were similar to controls (NS). But even though the antigenic levels were lower, the functional activity was lower in EMF patients.

\section{Discussion}

From the present study it appears obvious that a majority of the patients with endomyocardial fibrosis tested (94.4\%) have some type of Protein C deficiency. The proportion was equal, 44.4\% each had Type 1 and Type 2 deficiency.

That the thrombosis occurring in endomyocardial fibrosis adds

\begin{tabular}{|l|c|c|c|}
\hline & Patients (18) & Controls (18) & t test \\
\hline Functional Assay & $(4 \%-130 \%)$ & $(28.87 \%-210 \%)$ & - \\
\hline $60.52-28.06 \%$ & $103+44.58$ & $\mathrm{p}<.01$ & - \\
\hline By Immunoelectropheresis & $79.73+26.88 \%$ & $85.23+30.02 \%$ & $\mathrm{NS}$ \\
\hline
\end{tabular}

Table 2: Protein $\mathrm{C}$ levels in patient and controls (Patients with Endomyocardial fibrosis).

\begin{tabular}{|l|c|c|c|c|c|}
\hline & Sample size & Normal & Type I & Type 2 & Atypical \\
\hline Patients & 18 & 1 & 8 & 8 & 1 \\
\hline Controls & 18 & 12 & 3 & 1 & 2 \\
\hline
\end{tabular}

Normal profile-Antigen normal, Functionally Normal

Type 1 deficiency-Antigen deficient and functionally deficient

Type 2 Deficiency-Antigen normal and functionally deficient

Atypical type-Undefined category- Antigen reduced but functionally normal

Table 3: Types of Deficiency of Protein C seen among patients and controls. to the morbidity and mortality of endomyocardial fibrosis is known. It may well appear that hereditary deficiency of Protein C type 2 may be an additional, or even an important factor in predisposing patients with endomyocardial fibrosis for the development of intracardiac thrombi. Hitherto, reported families of protein C deficiency all had Type I deficiency, and all had a major thrombotic event of deep venous thrombosis. The thrombotic pattern of Type 2 protein $\mathrm{C}$ deficiency is not known.

In Type 1 deficiency the ratio of antigenic to functional activity is normal. In type 2 deficiency the ratio of antigenic to functional activity is abnormal. The antigenic levels are normal but the functional activity is low.

In one of the family pictures both the proband and the father had type II deficiency, that supports an autosomal dominant pattern of inheritance, while his mother was normal. In protein $\mathrm{C}$ deficiency an autosomal dominant inheritance has been described.

The second family shows that both the mother and the son have Type I deficiency. It is therefore possible that Protein $\mathrm{C}$ deficiency is associated with endomyocardial fibrosis and contributes to the pathogenesis of the disorder, if one accepts the hypothesis that organization of the mural thrombus results in fibrotic lesions on the endocardial surface.

\section{Thrombosis in endomyocardial fibrosis}

Previous workers [10] have postulated a thrombogenic theory for the causation of endomyocardial fibrosis. The endocardial thickening observed has been considered to be due to incorporation of thrombus into the endocardium. It is possible that the formation of minute intracardiac thrombi contribute to the endocardial thickening, while protein $\mathrm{C}$ deficiency in endomyocardial fibrosis predisposed the patients to intracardiac thrombi [15].

Balakrishnan et al. [16] have demonstrated neovascularity in 52.2\% of patients with endomyocardial fibrosis on coronary angiography. One of the patient's with neovascularity in the right atrium had a large right atrial thrombus at autopsy. It is possible that this neovascularity was the intermediate phase of the resolution of mural thrombi.

And we postulate that the predisposition to intracardiac thrombi is inherited due to protein $\mathrm{C}$ deficiency. In our series of 154 medically treated patients with endomyocardial fibrosis intracavitary thrombi were observed in $8 / 154=5.78 \%$. Of these 3 had large right atrial thrombi and one patient had a right atrial thrombus with a thrombus extending from the deep veins to the inferior vena cava and hepatic veins [5].

In our earlier series [4] 11/145 patients had intracardiac thrombi. During a follow-up period of 334 patient years 25 episodes of embolism occurred in 24 patients with endomyocardial fibrosis. The sites of embolism were Iliofemoral in 6, pulmonary in 10, carotid in 8 and mesenteric in 1. Embolism was also one of the complications leading to death in this series.

Protein $\mathrm{C}$ deficiency is an inherited disorder. Nair and Balakrishnan [17] have demonstrated some factors in endomyocardial fibrosis may be inherited. Dermatoglyphics are polymorphic inherited traits. In endomyocardial fibrosis she has shown increase in the frequency of whorls, in the finger tips and Sidney lines compared to controls. A higher frequency of absent/abortive main $C$ line in males with endomyocardial fibrosis and $\mathrm{C}$ lines terminating in the interdigital area in females was also seen. These findings supported the proposition of the presence of a greater genetic threshold in affected males. Protein $\mathrm{C}$ deficiency present on a congenital basis could co-exist with patients with endomyocardial fibrosis. 
Citation: Gupta PN, Balakrishnan KG, Kartha CC (2013) Decreased Protein C Levels in Endomyocardial Fibrosis: The Possible Significance. J Blood Disorders Transf 4: 170. doi: 10.4172/2155-9864.1000170

Page 4 of 4

The protein $\mathrm{C}$ deficiency we have observed is unlikely to be due to hepatic dysfunction as only patient without liver enlargement, or those off diuretics were included in the present study.

We ourself have repeated reported intracardiac thrombi in endomyocardial fibrosis $[4,5]$. We also have reported that treatment with warfarin helps improve survival [5]. So maybe this is also a link in the arm of the pathogenesis of endomyocardial fibrosis where protein $\mathrm{C}$ deficiency is only the final straw on the camels back of the disease process in endomyocardial fibrosis. Thrombi of the size described in one of our reports should have some other pathogenesis [18].

\section{Acknowledgements}

We gratefully acknowledge the help of the Director of Sri Chitra Tirunal Institute for Medical Sciences in helping provide the facilities for the study. We also acknowledge the ICMR who supported Dr Prabha Nini Gupta as an ICMR Talent scholar, during this study. At this time DR Prabha Nini Gupta was working in SCTIMST in the ICMR Center for Research in Cardiomyopathies.

\section{References}

1. Davies JN, Ball JD (1955) The pathology of endomyocardial fibrosis in Uganda Br Heart J 17: 337-359.

2. Shaper AG, Hutt MS, Coles RM (1968) Necropsy study of endomyocardial fibrosis and rheumatic heart disease in Uganda 1950-1965. Br Heart J 30: 391-401.

3. BLACK M, FOWLER JM (1965) ENDOMYOCARDIAL FIBROSIS IN BRITAIN Br Med J 1: 682-686.

4. Gupta PN, Valiathan MS, Balakrishnan KG, Kartha CC, Ghosh MK (1989) Clinical course of endomyocardial fibrosis. Br Heart J 62: 450-454.

5. Kunju M S, Gupta PN, Suresh K (2011) The Medical treatment of Endomyocardia fibrosis. Heart Asia 3: 120-123.

6. Stenflo J (1984) Structure and function of protein C. Semin Thromb Hemost 10: $109-121$
7. Broekmaus AW, Bertina RM (1985) Protein C in Recent Advances in Blood Coagulation. (4th Edn.), Poller, Churchill Livingstone, London, pp-117-137.

8. Bertina RM, Broekmans AW, Krommenhoek-van Es C, van Wijngaarden A (1984) The use of a functional and immunologic assay for plasma protein C in the study of the heterogeneity of congenital protein $\mathrm{C}$ deficiency. Thromb Haemost 51: 1-5.

9. Broekmans AW, Veltkamp JJ, Bertina RM (1983) Congenital protein C deficiency and venous thromboembolism. A study of three Dutch families. N Engl J Med 309: 340-344.

10. Shaper AG, Wright DH (1963) Intracardiac Thrombosis And Embolism in Endomyocardial Fibrosis in Uganda. Br Heart J 25: 502-508.

11. Bijlsma F (1976) "The variation in Endomyocardial fibrosis." Trop Geogr Med 1928-1999.

12. Kartha CC, Sandhyamani S (1985)An autopsy study of tropical endomyocardial fibrosis in Kerala. Indian J Med Res 82: 439-446.

13. Valiathan MS, Balakrishnan KG, Sankarkumar R, Kartha CC (1987) Surgical treatment of endomyocardial fibrosis. Ann Thorac Surg 43: 68-73.

14. Sapru RP, Balakrishnan KG, Iyer SS, Shanmugan J, Ashok PP, et al. (1983) "Haematological, Biochemical ,immunological and electrophysiological studies in Endomyocardial fibrosis." In: Sapru PR (Edr) Endomyocardial fibrosis in India, ICMR, New Delhi, pp-175-182.

15. OKADA R (1961) Clinicopathological study on the thickening of parieta endocardium in the adult heart. Jpn Heart J 2: 220-255.

16. Balakrishnan KG, Sasidharan K, Venkitachalam CG, Sapru RP (1983) Coronary angiographic features in endomyocardial fibrosis. Cardiology 70: 121-126.

17. Nair RR, Balakrishnan KG (1987) Dermatoglyphic studies in endomyocardial fibrosis. Indian J Med Res 85: 91-93.

18. Gupta PN, Kunju MS, Vishwanathan S, Thomas JM, Kumar BR (2013) A uncommon picture of endomyocardial fibrosis:no embolism yet. Heart Asia 5: 171-173. 